\title{
Polski Grand Tour na przełomie XVIII i XIX wieku*
}

\section{Polish Grand Tour in the $18^{\text {th }}$ and $19^{\text {th }}$ century}

\section{(i) $\ominus$}

http://dx.doi.org/10.12775/KLIO.2015.033

W

Pałacu Staszica w Warszawie 12-13 XI 2013 roku odbyła się ogólnopolska konferencja naukowa „Polski Grand Tour w XVIII wieku”. Spotkanie zorganizowane zostało przez Pracownię Literatury Oświecenia z Instytutu Badań Literackich Polskiej Akademii Nauk przy współudziale Polskiego Towarzystwa Badań nad Wiekiem Osiemnastym oraz Muzeum Pałacu Króla Jana III w Wilanowie. Owocem konferencji jest książka Polski Grand Tour w XVIII i poczattkach XIX wieku pod redakcją badaczki osiemnastowiecznych pamiętników Agaty Roćko.

W rodzimej literaturze całościowych opracowań doczekały się przede wszystkim podróże edukacyjne z XVI i XVII wieku ${ }^{1}$. Dotyczą one wywodzącej się jeszcze ze średniowiecza peregrinatio academica podejmowanej w celu odbycia nauki, głównie na zachodnich uniwersytetach, oraz jej odmiany - Grand Tour. „Wielka podróż” pojawia się w połowie XVII wieku, kiedy szlachecka tura obok tradycyjnego aspektu poznawczo-edukacyjnego zyskuje element turystyczno-towarzysko-przyjemnościowy. W XVIII wieku taki charakter podróży zaczyna dominować,

* Polski Grand Tour w XVIII i początkach XIX wieku, red. A. Roćko, Muzeum Pałacu Króla Jana III w Wilanowie, Warszawa 2014, ss. 465, ISBN: 978-83-63580-39-1.

${ }^{1}$ Por. klasyczne już prace A. Mączaka: Peregrynacje, wojaże, turystyka, Warszawa 1984 i 2004, Życie codzienne w podróżach po Europie w XVI i XVII wieku, Warszawa 1978 i Odkrywanie Europy. Podróże w czasach renesansu i baroku, Gdańsk 1998. Ostatnio: A. Kucharski, Theatrum peregrinandi. Poznawcze aspekty staropolskich podróży w epoce późnego baroku, Toruń 2013. 
co nie umknęło uwadze zagranicznych badaczy, szczególnie angielskich, przez których „wielka podróż” badana jest od wielu lat². Polski Grand Tour jak do tej pory nie był przedmiotem szerszej analizy, dzięki czemu praca ma szczególną wartość ${ }^{3}$.

Książka ma charakter interdyscyplinarny. Dwadzieścia jeden artykułów pióra historyków, historyków literatury, kultury, sztuki oraz edukacji, chronologicznie uporządkowane zostało w trzech częściach: Przemiany Grand Tour, Wokót Grand Tour i Nie tylko Grand Tour. Praca zawiera ponadto wstęp oraz dwa indeksy: nazw geograficznych i osobowy. Układ taki oddaje specyfikę polskich podróży zagranicznych, ich odmiany i przemiany, a także pokazuje samych podróżników i ich motywacje. Obszerny wykład (465 stron) dotyczy „wielkiej podróży” jako zjawiska charakterystycznego dla Europy, jak i Rzeczpospolitej w XVIII i początkach XIX wieku. Niejednokrotnie autorzy wykraczają poza te ramy, wracając do wieku XVII. Dzięki temu obserwujemy omawiane zjawisko w szerszej perspektywie, jednocześnie otrzymujemy kontekst europejski, gdzie, szczególnie w Anglii, zwyczaj odbywania europejskiej peregrynacji pojawił się i popularny był wcześniej - w drugiej połowie XVII wieku. Dla niektórych badaczy europejskie wędrówki po ogładę kończą się wraz z rewolucją francuską, dla innych wraz z pojawieniem się pierwszych biur podróży oferujących wycieczki turystyczne w latach czterdziestych XIX wieku. W recenzowanej pracy przyjęto tę drugą datę, co również wydaje się uzasadnione.

Część pierwsza Polskiego Grand Tour poświęcona została przemianom „wielkiej podróży”. W tekście wstępnym Marek Bratuń opisuje narodziny, rozwój i zmierzch zjawiska. Richard Lassels, który jako pierwszy użył pojęcia Grand Tour, uważał, że tylko ten, kto odbył podróż do Francji

${ }^{2}$ Chociażby: J. Black, Italy and the Grand Tour, Yale 2003; idem, The British Abroad. The Grand Tour in the Eighteenth Century, Sutton 2003 czy E. Chaney, The Evolution of the Grand Tour: Anglo-Italian Cultural Relations since the Renaissance, London 2000.

${ }^{3}$ Wśród polskich prac omawiających Grand Tour wymienić można: M. Bratuń, $Z$ dziejów europejskiego Grand Tour w XVII i XVIII wieku, „Kwartalnik Opolski” 2003, $\mathrm{nr}$ 1, rok 49, s. 7-12 czy idem, „Ten wykwintny, wyksztatcony Europejczyk”. Zagraniczne studia i podróże edukacyjne Michata Jerzego Wandalina Mniszcha w latach 1762-1768, Opole 2002. 
i Italii, może w pełni zrozumieć europejską kulturę i sztukę. Podróżując, peregrynant studiował na krajowych uniwersytetach, uczył się języków obcych i zapoznawał z europejską arystokracją i stosunkami panującymi nie tylko we Francji i Italii, ale w krajach Rzeszy, Holandii czy Anglii. Aby proces kształtowania dobrego gustu dokonał się w pełni, w podróż należało udać się między szesnastym a dwudziestym rokiem życia. W ten sposób - jak podkreśla autor - wielka podróż „stanowi ważny element w procesie kształcenia europejskich elit XVII i XVIII stulecia” (s. 21). Oczywiście wzór zmieniano wedle własnych celów i możliwości: podróżowano dłużej bądź krócej niż zalecane trzy lata, skracano trasę (kleine Tour) lub też wysyłano w podróż coraz to starszych peregrynantów (niekiedy granicę przesuwano do trzydziestego roku życia).

W rodzimej wersji takiej podróży widzimy elementy modelu stworzonego przez Brytyjczyków: okrężna podróż trwała kilka lat, wiodła przez wiele państw, pochłaniała sporo środków finansowych, z których nie zawsze młodzi ludzie i ich opiekunowie należycie korzystali. Nic zatem dziwnego, że staropolscy teoretycy wychowania zastanawiali się nad celowością tego typu wypraw. Debatę o pozytywnych i negatywnych skutkach Grand Tour wśród teoretyków wychowania przybliża Urszula Kicińska (Pedagogiczny aspekt podrózowania $w$ dawnej Polsce). Na przełomie XVII i XVIII wieku staropolscy pedagodzy nie podchodzili już z takim entuzjazmem do zagadnienia, jak we wcześniejszym okresie, często uznając podróże za zbyteczne i próżne. Nic zatem dziwnego, że proponowali zmodyfikować wyprawę pod kątem obywatelskiego wychowania. Uwagi te znane są jednak w literaturze przedmiotu i nie wnoszą wiele nowego do dyskusjí.

Praca, obok rozważań teoretycznych (Pierwiastek osobisty w oświeceniowych dziennikach podróży Magdaleny Partyki) i ogólnych uwag o najpopularniejszych trendach Grand Tour (Podróże Polaków do Italii $w$ drugiej potowie XVIII wieku: kontekst neapolitański Angeli Sołtys), przynosi

${ }^{4}$ Wypowiedzi staropolskich teoretyków wychowania o celach Grand Tour znajdujemy chociażby w: M. Kamecka, „Do cudzych krajów”. Edukacyjne podróże szlachty polskiej do Francji w epoce saskiej, Białystok 2012, s. 33-56 (Rozdział: Edukacja zagraniczna w staropolskich koncepcjach pedagogicznych). 
także opisy jednostkowych podróży. Mówiąc $O$ zagranicznych podróżach Janusza Modesta Sanguszki, należy zastanowić się nad pożytecznością peregrynacji, o którą tak martwili się staropolscy pedagodzy. Celem podjęcia wędrówki był nie tylko wypoczynek i poszerzanie horyzontów myślowych. Wyprawa wiązała się z późniejszym rozwojem karier szlachty, jej działalnością publiczną i polityczną w Rzeczpospolitej. Świadoma tej zależności była Barbara Sanguszkowa, która nie szczędziła środków na Grand Tour syna Janusza, który odbył dwie podróże edukacyjne. Pieczołowicie przygotowane, poprzedzone domowym kształceniem zagraniczne wojaże zakładały nabycie określonej ogłady towarzyskiej i poznanie europejskich miast (pierwsza z lat 1762-1763) oraz edukację (druga z lat 1769-1769). Oczekiwania Sanguszkowej, jak wielu rodziców wysyłających synów za granicę, były duże, zakładały naukę języków obcych, literatury, historii, geografii chronologii, fizyki eksperymentalnej oraz chemii. Obok książek Sanguszko miał poznawać salony i elitarne towarzystwo. Niestety książę skupił się na tym drugim aspekcie podróży, ulegając pokusom świata towarzyskiego i rozrzutności. Zmiana preceptora spowodowała, że niezwykle drogi wyjazd udało się „uratować”, co - jak podkreśla Agnieszka Jakuboszczak - dowodzi istotnej roli guwernera oraz kontroli rodzicielskiej w edukacji i zagranicznym życiu młodych szlachciców.

Druga część książki, zatytułowana Wokót Grand Tour, pokazuje efekty podróży zagranicznych. Z europejskiego wojażu oprócz dziennika podróży przywożono różnego typu pamiątki. Jednym ze sposobów uwiecznienia wielkiej podróży był portret. Katarzyna Jagiełło-Jakubaszek (Portrety polskich dam jako pamiątki ich wielkiej podróży) opisuje go jako obraz przedstawiający postać „w swobodnej, ale jednocześnie eleganckiej pozie (często ze skrzyżowanymi nogami), w otoczeniu eleganckich rekwizytów o artystycznym charakterze [...] antycznych figur, fryzów czy kolumn” (s. 188-189), często na tle rzymskiego krajobrazu lub architektury, ewokujący charakter i miejsce peregrynacji. Do najwybitniejszych portrecistów epoki „wielkiej podróży” należał Pompeo Batoni. Przez trzy dekady swojej twórczości Batoni ugruntował formułę portretu Grand Tour i miał kilkuset klientów, wśród których znajdujemy polskie podróżniczki (m.in. Józefinę Amalię Potocką czy Aleksandrę i Izabelę z Lubomirskich Potockie). 
Obok widocznych efektów podróży ta część pracy podejmuje trudniejszą do uchwycenia kulturotwórczą cechę Grand Tour. Postrzeganie samej Italii, jak i myślenie o całej europejskiej kulturze wpływały na kształtowanie się tożsamości arystokracji poszczególnych państw. Zestawienie podobieństw i różnic w postrzeganiu europejskiej kultury na przykładzie Anny Amalii von Sachsen-Weimar-Eisenach i Izabeli z Flemmingów Czartoryskiej prezentuje Renata Dampc-Jarosz. Podróż księżnej Weimaru oraz żywe zainteresowanie Włochami generałowej ziem podolskich pokazuje zakorzenienie obu arystokratek w tradycji europejskiej, jednocześnie oddaje indywidualne podejście do tejże spuścizny. Weimar oraz Puławy, oprócz tego, że były centrum osiemnastowiecznej myśli i kultury, są dowodem $\mathrm{z}$ jednej strony wzmożonego zainteresowania antycznym dziedzictwem, z drugiej zaś budzącej się świadomości narodowej europejskiej arystokracji, widocznej chociażby w pielęgnowaniu języka narodowego.

W trzeciej części omówione zostały peregrynacje przedstawicieli mieszczaństwa oraz duchowieństwa Rzeczpospolitej Obojga Narodów. Dla mieszkańców polskich miast, które od XVI wieku coraz bardziej oddalają się od Europy Zachodniej i tracą na znaczeniu, podróże edukacyjne były jednym ze sposobów utrzymania odpowiedniej pozycji ekonomicznej oraz kulturalnej. Kamila Szymańska zauważa, że należące do Leszczyńskich i Sułkowskich Leszno to jedno z miast, w których tradycja zagranicznej podróży edukacyjnej była stale obecna i silna. Dowodem są wyprawy do niemieckich, szwajcarskich i holenderskich uniwersytetów (m.in. Frankfurt nad Odrą, Lipsk czy Wittenberga) podejmowane przez protestancką młodzież leszczyńską. Wśród niej znajdujemy kandydatów do stanu duchownego (braci czeskich czy ewangelików), studentów medycyny, potomków rzemieślników i kupców. Należy zgodzić się z autorką, która uważa, że w biografii przedstawiciela mieszczańskich elit peregrynacje odgrywały ważną rolę. Inaczej niż w przypadku arystokracji, stawały się sposobem zdobycia kontaktów nie tyle przydatnych, jak w przypadku kupców, ile wręcz nieodzownych - wśród członków wspólnot kościelnych starających się zacieśniać więź religijną. Tutaj można zadać pytanie o zasadność określenia tego typu podróży mianem Grand Tour, gdyż bardziej związane wydają się z typem znanej i wykształconej w początkach epoki nowożytnej podróży na zagraniczny uniwersytet po dyplom gwarantujący 
zawód. Praktyczny charakter dominuje w tych przypadkach nad aspektem rozrywkowym podróżowania, choć oczywiście wcale go nie wyklucza.

W podróży duchownych z kolei (artykuły Bogdana Roka, Magdaleny Ślusarskiej i Tomasza Chachulskiego) dominującym kierunkiem był Rzym. Włoskie miasto wśród księży i zakonników cieszyło się popularnością z powodu stałej obecności papieża. Obok doznań duchowych i emocji związanych z błogosławieństwem głowy Kościoła, w relacjach pamiętnikarzy znajdujemy opis szeregu zwiedzanych miejsc, do których naturalnie należą kościoły i obiekty związane z historią chrześcijaństwa. Aby te nie zostały pominięte, dla pobożnych wędrowców tworzono specjalne przewodniki, do których należy np. Kościoty, malowania znaczniejsze $w$ Rzymie, $w$ niektórych miastach wtoskich, niemieckich, francuskich, polskich, podtug opisania innych ode mnie uważane pióra Pawła Ksawerego Brzostowskiego. Tak opracowane poradniki służyły celom informacyjnym oraz edukacyjnym, ich autorzy chcieli pokazać Rzym oraz całe Włochy jako centrum kultury i świata chrześcijańskiego, a nie antycznego, starożytnego, który wybijał się na pierwszy plan u świeckich wędrowców.

Praca przynosi obraz Grand Tour podejmowanego głównie przez arystokrację, niestety niewiele uwagi poświęcono podróżom pozostałych warstw społecznych. Pewnym wytłumaczeniem takiego ujęcia zagadnienia jest oczywiście brak źródeł. Zostając przy dokumentach pisanych, należy zauważyć, że w książce nie pojawia się wiele nowych świadectw, rozważania autorów opierają się w większości na tym, co zostało wydane i jest dobrze znane badaczom. Cała praca jednak, co należy podkreślić, opiera się nie tylko na materiałach jednego typu, znajdujemy w niej artykuły związane z analizą dzieł sztuki: malarstwa, rzeźby czy grafiki. Dzięki temu Grand Tour jawi się jako szersze zjawisko, które - obok aspektu edukacyjnego wyraźnie wpływało na kształtowanie się gustów artystycznych i kanonów sztuki, co prowadziło do rozwoju tychże w Rzeczpospolitej.

Recenzowaną pozycję należy uznać za ważne osiągnięcie. Wyłaniający się z niej obraz Grand Tour nie ma charakteru statycznego, obserwujemy jego narodziny i późniejsze przemiany. Książka pomaga również uchwycić specyfikę polskiej wielkiej podróży wynikającą z odmiennej tradycji i mentalności szlachty polskiej. Zasygnalizowany w pracy problem ze stworzeniem jednej definicji oraz istnienie różnych tradycji podróży w XVIII 
i XIX wieku otwiera w Polsce, toczącą się od lat zagranicą, dyskusję nad szeroko rozumianym Grand Tour i jest jej cennym osiągnięciem.

Eukasz Wróbel 